\title{
VIOLENCE AT SPORTS EVENTS - PHENOMENOLOGICAL CHARACTERISTICS AND PRACTICAL PROBLEMS
}

\begin{abstract}
In Republic of Serbia, violence at sports events represents a problem which is being reviewed with every new major sports event. A problem that goes beyond the scope of the sport, affecting topics of general crime, economics, and even the relationship between states. By forming a holistic perspective, the authors point out the need to revise the phenomenological framework of the previously mentioned phenomenon and the utopian nature of current preventive ideas. It is only by formulating a systemic criminal-law response that encompasses wider criminal frameworks, there are also considered the possibilities of normalization the sports events within the national framework.
\end{abstract}

Keywords: Sport, Violence, Penal Policy, Criminal Act

\section{Introduction}

Violence at sports events is a rather extensively elaborated topic by domestic authors of legal and criminological determination (Stevanović, 2017, p.172; Jovanović \& Pašalić, 2016, p. 397). It is a multidimensional phenomenon, which has been attracting the attention of both the lay and professional public for several decades in the Republic of Serbia and the region (Veselinović, Ivanović, Zenović \& Stanojković, 2015, p. 68). In other words,

\footnotetext{
*LLM, The Ministry of Interior, Kikinda, Serbia, e-mail: babicbranislav81@gmail.com

** LLM, Teaching Assistant, The Faculty of Law for Commerce and Judiciary in Novi Sad, The University of Business Academy in Novi Sad, Serbia, e-mail: anja.koprivica@pravni-fakultet.info
} 
it is a problem that is being re-actualized with practically every new sporting event that mobilizes a larger number of "fans" (Šuput, 2010, pp. 233-263). Following various sources, the subject context has been linked to the loss of life, both at the sports venues themselves, where certain events were held and in a somewhat broader spatial context, which is, directly and indirectly, related to a given "fan" subculture. Attacks on members of the police force, substantial property damage, and even incidents that were projected on the field of international relations, seem to be a constant in sports iconography in today's Serbia. Guided by the same framework, violence at sports events seems to have evolved in a criminological-phenomenological sense (Mršević, 2014 , p. 54). Starting from by defining sports hooligans, as poorly organized groups or individuals, of a violent nature, who are identified as supporters of a sports club, the fan context is now associated with high-level criminal groups (Mršević, 2016, p. 11). Drug distribution, drug market control, and the killing of "fan leaders" are increasingly mentioned as part of the broader context of the phenomenon. Sports motives seem more like a vale of violent domination intended to hide criminally oriented rivals than an authentic phenomenon that has anything to do with sports.

Following the national framework of events, in which members of fan groups intercepted citizens on the highway, endangering the safety and property of road users, as well as the fact that certain fan groups endangered the safety of players and their managers, it is clear that the violent context does not affect only those "fans" who are active sympathizers of a club or fan group. The uncontrolled torrent of violence that is associated with a phenomenon in question has an indiscriminate orientation, affecting completely random citizens. This situation raises the question of personal feelings of security of citizens and trust in state bodies, and their ability to ensure order and security. Only considering the iconography repeated countless times in which members of the police under "full war equipment" must prevent and suppress large-scale fan conflicts, it is clear that maintaining the current phenomenological image hurts citizens.

Finally, violence at sports events has a clear economic impact (Smoljić, 2010, p. 290). Vandalizing and setting fire to the infrastructure of sports facilities seems to be part of the calculated and acceptable costs of sports events. it should be added that domestic clubs are, as a rule, financially punished almost after every major international match, precisely because of the behavior of fans, either in a violent, racist context or because of the abuse of illegal fan props. Considering the possibility of violence and the fear of violent incidents, a significant number of citizens avoid such manifestations. In that 
way, not only financial damage is incurred by sports clubs, but also a certain influence is created on young people, in which sport is not a place of positive development, but a violent arena, which should be avoided.

Summarizing the above, the aim of this paper includes an integrative socio-pedagogical, criminological and legal perspective. In addition to the analysis of the current phenomenological context, a critical review of the existing social problem-solving strategy will be made, with the articulation of possible proposals for their improvement. Guided by the positive experiences of other countries, attempts will be made to emphasize critical zones of national practice, and to formulate the perquisites of effective multi-level prevention of the phenomenon in question.

\section{Violence at sporting events from a phenomenological perspective}

Guided by the title of this paper, which points to the discrepancy between the normative and practical solutions, it is necessary to point out the difficulties in precisely determining the phenomenological and etiological features of violence at sporting events. According to the available national statistical and scientific reports, it seems practically impossible to precisely determine the forms, frequency, scope, consequences of the phenomenon in question, and the accompanying directions of social reaction. Thus, some authors, analyzing the case law, look for answers within the selective framework of territorial judicial jurisdiction. Only by processing the relevant court judgments on the subject matter, it can be concluded that a large number of covered cases are isolated incidents (at rural and suburban (football) matches) (Dimovski \& Ilić, 2015, p. 129). Although, strictly speaking, these are the same illegal behaviors, it is clear that the consulting case law is not comparable to the mass scenes of fan violence at large sports arenas. This primarily stands out in terms of the degree of social danger, and all the previously mentioned social value elements.

Having in mind the need for resource engagement, the number of mobilized members of the police, medical staff, and private security, a more realistic picture can be obtained by selective analysis of only larger sports events, which gather tens of thousands of fans. Clearly, these are either international duels or so-called "derbies" of leading national clubs.

A representative example of this large scale violence is the paper by authors Subošić and Kekić (Subošić \& Kekić, 2012, p. 479). The mentioned authors find that in the period between 2009 and 2011, 134,120 sports events 
were held in the Republic of Serbia. At the same time, only 49 cases of severe bodily injury to citizens and only 2 cases of severe bodily injury to police officers were registered during the observed timeframe. This is a scientificmethodological approach that does not make any distinction between sports events, in terms of the number of citizens, the degree of security risk, and the requirement of mobilized resources.

A debatable interpretive perspective can be seen in the reports given by the police force. In the context of the previously mentioned large sports gatherings, reports indicate to dozens of persons deprived of liberty and injured, including police officers. Even by layman's observation of violent scenes in sports stands, it seems that the number of persons who are in some way legally prosecuted does not even come close to the number of persons who participate in the demonstration of violence. Consequently, it can be concluded that most of those who partake in this "fan choreography" actually successfully avoid any misdemeanor or criminal prosecution. Therefore, the available official indicators do not reflect the true picture of the frequency and form of this type of behavior. Some media reports from neighboring countries territorially also testify to the extent of the inefficiency of the social reaction to this type of violent crime. For example, during one of the guest appearances of Serbian fans in Italy, a group of 300 people, who disturbed public order and peace on the city streets, threw various objects at bystanders, and participated in fights, was identified. Only as a result of police engagement, 50 people were deprived of liberty (17 people were detained), which leads to a simple mathematical calculation that $5 / 6$ of the perpetrators evaded any kind of responsibility. In that sense, the available court statistics on the number of indictments and convictions, actually represent only the tip of the iceberg of the real picture of violence (in Serbia as well) and not a real indicator of (high) efficiency of the legal system.

Returning to the examples of insufficiently representative statistics, it is worth referring again to the previously mentioned work of Subošić and Kekić (Subošić \& Kekić, 2012, p. 479). Mentioned authors find that in the sample of over 134,000 sports events, a total of only 211 people were detained by the police authorities. Hence, it could be concluded that the problem of violence at sports events does not even exist, because the number of detained persons is reduced to individual incidents, of statistically negligible importance. However, as the sample of the subject study is completely non-discriminatory in structure, and could have identified the football matches of Red Star and Partizan with the sports matches of the retiree's chess club from Mirijevo, it 
is clear that such a static presentation masks the real, urgent need for more decisive social intervention.

The phenomenological framework of the analysis must include other aspects. Fan subculture is organized around the idea of loyalty to a certain sports club, and support and motivation in sports. This type of activity leads to a clear consequent group identification of all members gathered around a given goal, which carries appropriate psychological gratifications. The feeling of belonging, individuals taking over the strength of the whole group, identification with the successes of the club, are clear psychological motives for "cheering" (Vučičević-Miladinović, 2008, p. 44; Subotić \& Dimitrijević, 2016, p. 517).

Nevertheless, analyzing the national context of the concept of fan groups, one observes a shift that is increasingly "separated" from the sports club itself as a central focal point. The mere existence of the "fan front" and the affiliated factions impose themselves as the goal, while the previously mentioned mechanism of group identification, one gets the impression, moves further and further away from the club context, adopting attributes of a violent fan group. The connection between the fans and the sports club is relative and less important, as evidenced by the fact that the so-called "fan leaders" not only change their positions within the factions of one club but move to "opposing camps" and completely different clubs. This kind of fan "taboo" that is not forgiven to athletes, in the violent culture of fans is very easily internalized, provoking a further explosion of violence. Although the given framework of the psychodynamics of fans and fan groups may not be of much interest to lawyers, criminological analysis finds that socially dangerous criminal activity takes place behind such processes. Although these claims are difficult to prove in a strictly scientific sense, numerous indicators suggest that leadership and participation within these groups appear as a screen or complementary scenario for other forms of criminal activity. Hence, accepting the assumption that violence at sports events is a facade of much more serious crime, not only carries important phenomenological corrections but also has key implications in the field of prevention and suppression. Guided by practical experiences and analysis of public discourse, it is not impossible to find sources that indicate that fans receive certain financial resources from clubs. Some interpretations of the behavior of fans at sports stadiums interpret violence as a form of blackmail against club administrations. The provocation of incidents and the consequent imposition of fines by international (football/basketball) bodies, which are measured in tens of thousands of euros, can be seen as a deliberate type of pressure from hooligans due to, in slang, "unpaid racket". Remaining 
in the same context, it is not unknown that criminally oriented individuals and groups often enter into a contractual relationship with young athletes, providing them with appropriate scholarships and benefits, in exchange for a percentage share in the profit they will make during a later transfer to a new club. Although the legal norms are often not violated in the formal legal sense, the public secret is the existence of various pressures, blackmail, and intimidation, both on the athletes themselves and the club management. Only having in mind that there are potentially millions (in foreign currencies) to be obtained, it is clear that sport is a very favorable framework for criminal manipulation. What is seen in the stands as "the hooliganism of uneducated young men" can find an interpretation in a significantly broader and more serious criminal framework.

The fact that physical violence against athletes, and even against members of the management of the largest clubs in Serbia, is not uncommon, testifies to the fact that this is a rather complex issue, which must certainly raise the question of the real causes of these behaviors. Placing violence at sports events in a more complex criminal scope sets the imperative of much more detailed scientific and professional phenomenological specifications. Although official reports identify bodily injuries or property damage as the most common consequences of this type of violence, the different etiological basis of the given behaviors places this phenomenon in a completely different context. Following the input of various authors, fan violence must also be viewed in the context of expressing political views, but also its abuse. From the early 90 s, unpleasant scenes on football, basketball, and even water polo courts bore the hallmarks of interethnic conflicts. However, limiting the scope of research to the domestic framework, some interpretations of public discourse place fan violence in the context of internal political struggles (Savković \& Đorđević, 2010, p. 15). If we accept the fact that young fans are often criminally inclined, it is not difficult to accept attitudes towards financially backing hooliganism, intending to destabilize the current regime, causing insecurity among citizens and creating a suitable ground for criticizing the government as incapable of solving a burning problem. The instrumentalization of this type of violence, therefore, far exceeds the narrow sports-centered point of view, demanding a significantly broader framework of social intervention. Summarizing the above-mentioned, although violence at sports events is easily recognizable, the same form of behavior can have completely different contextual and etiological bases. Hence, the phenomenon in question cannot be viewed as having a singular dimension, which requires a completely different strategy of social action in the direction of prevention and suppression. 


\section{Conceptual limitations of violence prevention at sports events}

Beginning with the well-known tragedy at the Heysel Stadium, in the mid-1980s, the problem of preventing violence at sporting events found its elaboration within different European and national (legislative) frameworks (Young, 1986, p. 260). Summarizing the strategic framework of action, the text of the European Convention on Spectator Violence and Misbehaviour at Sports Events and in particular at Football Matches formulates an overarching document, a multi-level framework of preventive action, which would systematically influence the prevention and suppression of the phenomenon (Š́uput, 2010, pp. 233-263).

In addition to the fact that in Serbia the Law on Prevention of Violence and Misconduct at Sports Events adopted in 2003, some 18 years after the adoption of the previously mentioned Convention, it is necessary to analyze certain segments of the framework it establishes (Ilić, 2016, p. 8). Most authors and experts dealing with the topic of violence at sports events agree in the conclusion that prevention is a key element in solving this problem. In this sense, some additional remarks should be made.

Thus, the very concept of prevention can be most easily divided into primary, secondary, and tertiary action. The application of appropriate social and educational measures, the use of the media to promote sports ideals through educational and other campaigns, the promotion of fair play, and the development of mutual respect between spectators and athletes are some of the basic and broadest frameworks, which are explained in the relevant national and international legal documents.

Although the given legal frame has a rather aesthetic and receptive overtone, one gets the impression that it is formulated in a significant discrepancy with reality and current needs. Thus, if educational and informative programs were implemented in the general population, and especially with young people, who have not yet shown violent patterns of behavior, a logical conclusion can be reached, that this is a process that requires continuous action over time. Only when it would be assumed that such a preventive concept can carry an advantage over intrafamily, economic, social-value and other contributing variables, this approach is inapplicable to thousands of young people who are already set in their violent orientation. That is, given the mentioned dynamics of action, the first effects could be expected only in a decade. What can be done with the current problem, therefore, remains an unanswered question. 
The second framework of (secondary) prevention would be oriented towards those persons who are at risk of adopting violent behaviors. And although this concept has positive aspects because it focuses only on at-risk individuals and groups, the question arises as to how the given persons would be motivated to participate in any meaningful program. If on one side of the equation there is delinquency, alcohol, drug abuse, and intoxication with a sense of group power, while on the other we have a (usually boring for young people) program of respect for human rights, diversity, equality, and tolerance, it is difficult to expect young people's enthusiasm for democracy and fair play. Even if we would assume by some miracle that 20,000 young people in Serbia want to be included in informative/educational programs, the question of resources, personnel, and forms of implementation of such programs certainly arises. When considering all the consequent requirements for the realization of a given form of prevention, one gets the impression that it is easier not to even start dealing with the given problem.

Finally, tertiary prevention (excluded from the classic legislative-penalty options) could include all those programs of support and reeducation towards those fans who already show violent tendencies in a structured way. An idea that in various sources is related to the more active participation of clubs, cooperation of clubs with fan cores, holding more frequent meetings, respecting ideas, discussions and encouraging cooperation (Božović, 2014, p. 180). Quite a nice concept that overlooks the fact that in Serbia, the club's fans are prone to the physical "education" of the players. That is, that at one instance, the security detail of the president of the sports club was attacked and beaten. A framework that overlooks the fact that club members themselves, coaches, often have aggressive and threatening outbursts towards fans, in which the notion of "slaughter" and "killing" is not unknown. Finally, should we mention the list of all "sports workers", which have been directly related to the classic forms of crime during the last decades? Moreover, Serbian sport is in such a situational context in which the murder of the Secretary-General of the Football Association has not been solved even after 17 years (Telegraf, 2018). With the leading and most risky clubs in the subject context, it is difficult to expect that such an idealized context of communication and cooperation can be realized in a criminalized atmosphere of a broader framework.

Not only do different authors point to international experiences, according to which one part of the fans is completely resilient to efforts of this type, but it is also worth returning to earlier phenomenological remarks. The education-oriented campaign seems completely meaningless if we categorize the subject phenomenon into broader criminal forms. Only when it is accepted 
that violence at sports events is not a matter of education and undirected energy discharge of young people, the only (currently) logical strategy can be discerned. One of the segments of suppression of this phenomenon includes the so-called situational prevention. Mostly, these are the requirements of several experts regarding the improvement of security systems at the sports venues (Kovačević-Lepojević \& Žunić-Pavlović, 2010, p. 330). Whether it is metal detectors, video surveillance, means of communication, or training of the security service, modern security architectures enable the minimization of the scope and consequences of violent incidents.

And although it is probably possible to devise a wide range of measures that would make it easier to control the behavior and movements of fans, the question arises as to the meaning of the necessary investments. Between the state investing tens, hundreds of thousands, or millions of euros in the safety of hooligans, it seems more sensible to invest in equipping school gyms. That is, if, as a society, we are incapable of controlling the behavior of a "handful" of hooligans without special investments, a ban on gatherings seems more logical than such resource allocation. That this is a rather bizarre situation is also evidenced by the (inaccessible) economic calculation. During the day when the "derbies" are held, the engagement of the police forces is visible, in such numbers, that one could expect an invasion on some smaller country, rather than that it's about a sports event. This is an extraordinary expense, paid by the taxpayers of this country, and who are largely not interested in whether Red Star will outplay Partizan or not. Only if we accept that the costs for hundreds/thousands of armored "turtles", as police officers with protective equipment are called in slang, are not enough, does it make sense to further waste money on modern security measures. That the mentioned resource allocation is unnecessary is evident with a simple conclusion. Some of these measures are actively applied today. For example, frisking fans, seizing pyrotechnics, or other items suitable for injury is a safety standard today. Still, does it have to be mentioned that at every big football match, the "torchlight" is part of the regular fan repertoire? Only in that sense, it can be concluded that modern means of detection do not make a significant contribution if they are limited by the omissions of those who directly apply them. It is in this sense that the training and readiness of the security service are often mentioned in scientific discussions. At the same time, reading the findings of various authors, one gets the impression that some of them have never actually been at a football match or experienced in real life the challenges that the security service is facing. For example, if we were to talk about the handball match of the women's clubs of the youth league in Valjevo, it would be logical that five security 
personnel would be able to intervene in the inappropriate or aggressive behavior of parents, dissatisfied with the game. When it comes to 5,000 fans, hooligans, often under the influence of alcohol or drugs, the only meaningful thing the security service can do is to inform the police and withdraw to safety. Any training and skills of a bare-handed individual in a marked vest seem useless.

\section{Criminal policy and strategy}

Accepting the fact that violence at sports events has deeper criminal roots, it is clear that state intervention cannot be limited to a decorative level. The malignant altered disease requires painful demands, which precede healing. As Suput concludes, perhaps the most painful thing in this fight today seems to be the establishment of political consensus and the will for decisive, uniform, and consistent application of preventive and repressive measures aimed at combating violence at sports events (Šuput, 2012, p. 77). That is, as the same author points out, selective treatment of "privileged" or "deserving" individuals (unknown criteria for acquiring merit and privilege) is one of the key obstacles to any meaningful effective outcome.

Returning to the reality in which business and money are often above (or next to) the law, it can be understood that the state cannot have equal reach in all criminal aspects, and especially high-financial criminal frameworks of sport. Although this attitude is devastating and degrades the very essence of the legal system, the current subject context raises some other doubts.

Analyzing the case law and media sources, the case of K.I. who presents himself in the media as the leader of the G3 faction of the fan group of the football club "Vojvodina". This is a person against whom exactly 20 criminal indictments were filed until 2014 alone (for various criminal acts), and he was acquitted 20 times. It is worth mentioning that in 2018, the public prosecutor gave up criminal prosecution of the same person, in the context of violent behavior at a sports event and obstruction of a state official in the line of duty, which further increased his positive score of non-conviction (Blic, 2014).

Although this is not an isolated case in Serbia, such statistical symptomatology points to dilemmas as to whether the court acted impartially and following the evidence in all cases. Or, are there incompetent people working in the police and the prosecutor's office who've failed to indict someone 21 times. Having in mind the aforementioned Law on Prevention of Violence and Misconduct at Sports Events, which has undergone various corrections since its adoption. Weaknesses of current solutions and possibilities for improvement are quite widely scientifically elaborated. Nevertheless, 
phenomenological observations indicate that the subject of the problem must be solved at a higher, criminal, and even systemic level.

That "fan violence" is a problem of extreme complexity can also be concluded from various media sources. Regardless of whether this is accurate information, the fact that in the context of hooligans, state authorities are also often criminalized explains why this problem is impossible to solve. For example, in the case of the murder of V.D., who was considered the leader of the Red Star football club fans, the newspaper columns were filled with texts about mutual accusations of high police officials, department heads, and the entire Belgrade administration (Alo, 2015). Without entering into the meaningfulness and justification of the mentioned articles, it seems unacceptable that there is any possibility for the state to flirt with criminals, giving them privileges before the law. Only such an untouchable position can lead to the incurability of the chronic problem of violence at sports events, the end of which is not in sight.

The given problem is not limited to these irregularities. Not only does the triad of police, prosecution, and the judiciary are not showing sufficiently integrated efficiency on the issue in question, but the creation of a paradoxical public discourse in which violence is supported is allowed. We can give two examples. During the guest appearance of the "Red Star" football players in Munich, during September 2019, one could read the newspaper headlines "Delije drive fear to their bones" or "German police trembles before Delije" (Serbia Today, 2019). While it is understandable that there is a desire to strengthen support for the home club in an important competition, the question arises as to whether the overall context is in collision with much more important goals than sport. We should keep in mind that only two years earlier, more than 2,300 police officers were hired in Cologne to secure a football match.

The fact that the "fan" Uroš Mišić, convicted (firstly for 10 years for attempted aggravated murder, later reduced to 5 and a half years) for violence at a sporting event, has become practically a cult figure, an idol of young people, who sought "Justice for Uroš" all over the city. At the same time, not only does the majority still not know the name of the victim, who was performing his police duty but there was a public debate about the possible contribution of the victim to his victimization. Finally, as Mršević states, in the trial costs for the defense, for as many as 6 lawyers, which is estimated at around 80,000 euros, in addition to the fans, the football club "Red Star" also participated (Mršević, 2014). 


\section{Instead of the conclusion}

The core of legal papers in Serbia that analyze the legal aspects of preventing and combating violence at sports events offers a fairly comprehensive nomotechnical and substantive critique of the existing legal texts. Various shortcomings, inconsistencies, or limitations of application of applicable legal norms have, to a large extent (and several times), have been thoroughly dealt with in scientific discussions. Further dissection of legal inconsistencies or restrictions in the application of certain legal provisions, serves more like duplication and retelling of what has already been written several times.

This kind of legal gymnastics seems restrictive for other reasons as well. By accepting all previous remarks that include value-cultural, systemic, political, legal-institutional problems, and by analyzing the legal texts, a very limited scope, only a partial insight/solution of the problem can be obtained. Solving a complex criminal problem by banning the sale of alcoholic beverages at a certain distance from the sports venue or by banning access to matches, seems to be only an aesthetic solution, not the essential.

Violence at sports events is a symptom of a disease of the entire system. A problem that permeates the whole society in the pyramid of social factors. The synergy of high cash incomes of sports societies, decades of functioning in the gray/criminal economic zone, the problem of corruption, and the sluggishness of the judiciary, are vital factors for resolving this problem.

The issue of club ownership structure, transparency of player transfers, regularity of the (football) league and "match-fixing", as well as clarification of the discrete and indirect connection of clubs/players with criminally inclined persons, is a question that should come to the forefront of priorities, before resolving "skirmishes" and "unrest" in the stands. Finally, even without the idea of criminalizing the clubs themselves, the imperative of an unequivocal reaction of the state towards all those persons who are in any way connected with fan groups, and who are immersed in crime, is imposed. This framework is so conspicuous that it is no longer a question of sports violence, but the existence of the basic qualities of the state and the state apparatus that enforces laws on its territory.

Talking about the reasons for the state's failure to solve the problem in question requires a multi-party analysis. However, can effects be expected in this regard at all, when case law reviews indicate that probation is the most common punishment in the context of violence at sporting events? Informing, educating, respecting rights and tolerance, as well as placing the hope that prevention will have an educational effect on bullies, stands against organized 
crime and the lucrative narcotics market. Psycho-pedagogical counseling can hardly, in the conditions of reality, have any significant contribution over those who earn millions in income from violent crime.

\title{
Babić Branislav
}

Master prava, Ministarstvo unutrašnjih poslova, Kikinda, Srbija

\section{Koprivica Anja}

Master pravnik, asistent, Pravni fakultet za privredu i pravosuđe u Novom Sadu, Univerzitet

Privredna akademija u Novom Sadu, Srbija

\section{NASILJE NA SPORTSKIM PRIREDBAMA - FENOMENOLOŠKA OBELEŽJA I PRAKTIČNI PROBLEMI}

\begin{abstract}
REZIME: Nasilje na sportskim priredbama predstavlja problem koji se u Republici Srbiji aktuelizuje sa svakim novim velikim sportskim susretom. To je problem koji svojim odrazima prevazilazi okvire sporta, zadirući u teme opšteg kriminala, ekonomije, pa i međudržavnih odnosa. Formirajući holističku perspektivu autori u radu ukazuju na potrebe revidiranja fenomenoloških okvira samog predmetnog fenomena, te utopičnost aktuelnih preventivnih ideja. Tek formulisanjem sistemskog krivičnopravnog odgovora koji obuhvata šire kriminalne okvire, sagledavaju se i mougćnosti normalizacije sportskih zbivanja u nacionanom okviru.
\end{abstract}

Ključne reči: Sport, nasilje, kaznena politika, krivično delo

\section{References}

1. Alo (2020). Šefovi policije ometali istragu ubistva Velibora Dunjića [Police Chiefs Obstruct Investigation into Velibor Dunjic's Murder]. Downloaded 2020, February 15 from http://arhiva.alo.rs/vesti/hronika/ sefovi-policije-ometali-istragu-ubistva-velibora-dunjica/81677

2. Blic (2020). Šef bande huligana oslobođen i 20. put [The Head of the Hooligan Gang Released for the $20^{\text {th }}$ Time]. Downloaded 2020, 
February 17 from https://www.blic.rs/vesti/hronika/sef-bande-huliganaosloboden-i-20-put/xz9pv5y

3. Božović, M. (2014). Suzbijanje nasilja na javnim skupovima i sportskim priredbama $\mathrm{u}$ evropskom pravnom prostoru [Combating violence at public gatherings and sporting events in the European legal space]. Megatrend revija, 11 (1), pp. 171-188

4. Dimovski, D. \& Ilić, I. (2015). Nasilje u sportu u Republici Srbiji: primer područja Višeg suda u Nišu [Violence in sports in the Republic of Serbia: An example of the area of the High Court in Niš]. NBP-Žurnal za kriminalistiku i pravo, 20 (1), pp. 119-133

5. Ilić, M. (2016). Huliganizam, kriminal i kaznena politika [Hooliganism, crime and penal policy ]. Društvena i tehnička istraživanja, 2 (1), pp. 1-12

6. Jovanović, S., Pašalic, Z. (2016). Maloletni učinioci prekršaja sa elementima nasilja [Juvenile delinquency with elements of violence]. Crimen, 7 (3), pp. 397-410

7. Kovačević-Lepojević, M. \& Žunić-Pavlović, V. (2012). Implementation of video surveillance in crime control, Specijalna edukacija $i$ rehabilitacija, 11 (2), pp. 325-345

8. Mršević, Z. (2014). Šest mitova o sportskom nasilju [Six myths about sports violence]. Zbornik Instituta za kriminološka i sociološka istraživanja, 33 (1), pp. 45-60

9. Mršević, Z. (2016). O nasilju navijača: navijačko nasilje: incidenti ili Rituali [About Fan Violence: Fan Violence: Incidents or Rituals]. In: Zeković A. (ured.), Bezbjednost $i$ osnovna prava: dimenzije i perspektive sigurnosti LGBT osoba [Security and fundamental rights: Dimensions and perspectives of LGBT security] (pp. 11-26). Podgorica: Vlada Crne Gore - Ministarstvo unutrašnjih poslova, Ministarstvo za ljudska i manjinska prava

10. Savković, M. \& Đorđević, S. (2010). Na putu prevencije nasilja na sportskim priredbama: predlog regionalnog okvira saradnje [Towards the prevention of violence at sports events: A proposal for a regional framework for cooperation]. Beograd: Beogradski centar za bezbednosnu politiku

11. Smoljić, M. (2010). Ekonomske štete od nasilja u športu [Economic damage from sports violence]. Hrvatski znanstveno stručni skup o menadžmentu u turizmu i sportu, 1 (1), pp. 288-300

12. Srbija danas (2020). Delije im uterale strah u kosti: Nemačka policija drhti pred Zvezdinim navijačima [Delije drve fear in the bones: German police trembles before Red Star's fans]. Downloaded 2020, February 15 from https://www.srbijadanas.com/sport/fudbal/delije-im-ulile-strah-u-kostinemacka-policija-drhti-pred-zvezdinim-navijacima-video-2019-09-16 
13. Stevanovic, A. (2017). Huliganizam, vandalizam i nasilničko ponašanje [Hooliganism, vandalism and violent behavior]. Crimen, 8 (2), pp. 172-188

14. Subošić, D. \& Kekić, D. (2012). Stanje i tendencije nasilja na sportskim priredbama u Republici Srbiji u periodu 2009-2011. godine [Status and tendencies of violence at sports events in the Republic of Serbia in the period of 2009-2011]. In: Dospaj M., (ured.), Efekti primene fizičke aktivnosti na antropološki status dece, omladine i odraslih [Effects of physical activity on the anthropological status of children, youth and adults] (pp. 478-486). Beograd: Fakultet sporta i fizičkog vaspitanja

15. Subotić, M. \& Dimitrijević, I. (2016). Faktor gomile u navijačkom nasilju [Crowd factor in fan violence]. Kultura polisa, 13 (29), pp. 511-526

16. Šuput, D. (2010). Pravni okvir koji uređuje borbu protiv nasilja na sportskim priredbama u evropskim državama [Legal framework governing the suppression of violence at sporting events in European countries]. Strani pravni život, 54 (1), pp. 233-263

17. Šuput, D. (2012). Problemi dokazivanja i procesuiranja delikata iz oblasti sporta [Problems of proving and prosecuting sports crimes]. Pravo teorija i praksa, 29 (4-6), pp. 75-88

18. Telegraf (2020). Najmoćniji fudbalski čovek Srbije ubijen u sačekuši: Tajna duga 14 godina još nije otkrivena [Serbia's most Powerful Football Man Gunned Down: The 14-year Secret has not yet been Uncovered!]. Downloaded 2020, February 15 from https://www.telegraf.rs/sport/ fudbal/2945902-najmocniji-fudbalski-covek-srbije-ubijen-u-sacekusitajna-duga-14-godina-jos-nije-otkrivena-video

19. Veselinović, J., Ivanović, M., Zenović, F. \& Stanojković, S. (2015). Policijske mere u suprotstavljanju huliganizmu na sportskim događajima [Police measures in counteracting hooliganism at sports events]. Menadžment u sportu, 6 (1), pp. 66-80

20. Vučičević-Miladinović, L. (2008). Psihologija navijača: sportski fan ili fanatik [Fan Psychology: Sports fan or fanatic]. Biznis i finansije, (45), pp. $46-56$

21. Young, K. (1986). The Killing Field: Themes in Mass Media Responses to the Heysel Stadium Riot, International Review for the Sociology of Sport, 21 (2-3), pp. 253-266

22. Zakon o sprečavanju nasilja i nedoličnog ponašanja na sportskim priredbama [Law on Prevention of Violence and Misconduct at Sports Event]. Službeni glasnik RS, no. 67/03, 101/05 - other law, 90/07, 72/09 - other law, 111/09, 104/13 - other law and 87/18 